\title{
Reliability and Validity of Facilities Management Competencies Instrument Using Partial Least Squares
}

\author{
Mariah Awang and Abdul Hakim Mohammad
}

\begin{abstract}
Facility management competency questionnaire was developed to measure the facility management competencies required by individuals who manage the facility or facilities manager at the polytechnic. This study was conducted to produce empirical evidence of the reliability and validity of the competency of questionnaires facility manager by using Partial Least Square. This study used 36 items derived from the professional bodies and previous studies. This questionnaire administered 661 officers who manage the facilities in the polytechnics. The questionnaire measures five constructs, namely Leadership in Organization and Human Resources Management, Services Management, Operation and Maintenance Management, Working Environment and Resource Management and Law Management with six-point Likert scale. Partial least squares; SmartPLS version 2.0, was used to test the reliability and validity of the questionnaire. Reliability index values obtained from all constructs is between 0.909 and 0.969 . This study also describes an arrangement of items in accordance with the importance being accorded agreed upon by those who manage the facilities in the polytechnics. Results acquired have proved questionnaires used have high reliability and validity for identifying facility manager competencies in polytechnic.
\end{abstract}

Index Terms-Facility management competencies, reliability, validity, partial least square.

\section{INTRODUCTION}

The importance of facility management competencies is not a new thing in discussing, especially in developed countries like United Kingdom, United States and Australia. Everyone needs facility management competencies to function while doing the duty effectively [1]. Facility Management competencies also been discussed at various levels, including, professional bodies, and higher education institution. For example of activities undertaken by them such as courses, seminars, workshops, etc. (website [2]-[4]). While in Malaysia the Minister of Works had emphasized to all asset managers, facility managers and maintenance contractors to improve their competencies in carrying out their respective responsibilities at Asset and Facility Management Conference Malaysia (NAFAM) [5]. Competition for employment has made Human Skills even more important. Hence, a study to identify the most facility management competencies with the current situation of this industry in Malaysia is appropriate. To ensure that the process of identifying the precise competence and quality, the

Manuscript received September 10, 2013; revised December 4, 2013

Mariah Awang is with the Department of Polytechnic Education, Ministry of Higher Education Malaysia or Universiti Teknologi Malaysia (e-mail: mariahawang@yahoo.com). questionnaire used for this study should have the reliability and validity due to the data, and the findings are recognized by all parties. A great many authors have discussed the requirements on the general competence of managers, e.g. [6]-[8], while others have concentrated on the demands placed on ICT managers [9]-[12].

Study the reliability and validity of of questionnaires is very important to maintain the accuracy of disability of questionnaires. The higher value for the reliability and validity of the questionnaire, the more accurate the data. Reliability is defined as a measure to determine the consistency of the scores of each item [13]. Consistency means that when the same items are tested multiple times on the same subject at different time intervals but still give a decision or answer score equal or nearly equal [14]. So, the validity is the appropriateness, truthfulness, meaningfulness and usefulness of questionnaires that enable data the inherent [15]. Consequently the objective of this article is divided into two: the first one; obtain the reliability of the facility management competencies of questionnaires. Second, find out the validity of facility management competencies of questionnaires. Therefore in order to achieve the objectives of this article, further discussion is the facility management competencies elements, methodologies, finding and discussion.

\section{FACILITY MANAGEMENT COMPETENCIES ELEMENT}

United Kingdom ten years ago has led to increased interest in the application of the competency framework in the development and selection of expert managers and general managers. Most of the works involved in developing this framework were focused upon the role of facilities managers [1]. Therefore, professional bodies such as the IFMA and the BIFM have adopted the competency framework as a basis for professional accreditation in the field of facility management [16]. These competency areas share some of the same competences: for example, in the field of human resources, communication competence and communication of information arise within the same field. Therefore, [17] have specified five areas of facility management competencies that are essential to realize the mission to the organization. Similarly, [16] listed thirteen competencies recommended for directors and senior managers of the facility, these being issues related to the environment, visionary building design, relevant law, project management, research and analysis, facility management process, real estate portfolio management, risk management, stress management, marketing, monitoring, managing conflict and managing 
time.

In contrast, [18] suggested four areas that should be prerequisites for professionals involved in facilities management, although he did not specify these areas as competencies. By referring to the literature and the above discussion, it is argued that these fields can be used as a guide for identifying competency requirements for polytechnic facility management. Then, in 2005, a further study listed ten key features for a facilities manager to be used as a reference for facility management competency [19], while the Institute of Higher Education Facilities Management Professionals in the Netherlands has identified nine key competencies for facility managers [20]. Meanwhile, as regards education organizations, [21] identified seventeen Higher Education Facility Management Associations but only four of these are active: the Association of Physical Plant Administrators (APPA) in the United States of America, the Association of University Directors of Estates (AUDE) in the United Kingdom, the Tertiary Education Facilities Management Association (TEFMA) in Australia and the Higher Education Facilities Management Association (HEFMA) in South Africa. Of these four associations, the only one that has indicated a list of core competency areas involved in higher education institutions is APPA, which sets out four areas of core competencies: General Administration \& Management, Operations \& Maintenance, Planning, Design \& Construction and Energy, Utilities \& Environment [22]. Besides that's in Malaysia there is only one preliminary study of competencies that facility manager have been conducted, of whom eight areas of facility management competencies identified at the polytechnic, namely managing people, managing resource, operation and maintenance, leadership and management, managing the working environment, understanding business organization, managing premise and managing services [23].

As such the research in facility management competencies should be viewed more closely. So by using a questionnaire which has the reliability and validity of the proposed that's the performance of services provided by organization will continue to be greatest. From previous literature [1], [16], [17], [20], [21] [23]-[32] facilities management professional bodies [33]-[37], and facility management associations of Higher Education Institutions in the United States (Association of Physical Plant Administrators (APPA)), the United Kingdom (Association of University Directors of Estates (AUDE)) and Australia (Tertiary Education Facilities Management Association (TEFMA)), we recommend eight areas of facility management competencies that need to be reviewed in order to realize the polytechnics' transformation plan, which was launched based on a synthesis of all of these sources of information. However, after the initial findings from [23] through statistical analysis (factor analysis), found facilities management competency areas for polytechnic is five. Subsequently, in light of the necessary competencies for facility manager and features that should in place, the competencies required for facilities manager in polytechnic are summarised in Table I.
TABLE I (a): THE FIVE AREAS OF POLYTECHNIC FACILITY MANAGER

\begin{tabular}{|c|c|c|}
\hline \multicolumn{3}{|c|}{ COMPETENCIES } \\
\hline Area of competencies & $\begin{array}{l}\begin{array}{l}\text { No. } \\
\text { of } \\
\text { Items }\end{array} \\
\end{array}$ & Sources \\
\hline $\begin{array}{l}\text { 1. Leadership in Organisation } \\
\text { and Human } \\
\text { Resource Management }\end{array}$ & (12) & \\
\hline Plan and sort the facility function & & [16]; [20]; [33]; ‘38] \\
\hline $\begin{array}{l}\text { Has the characteristics of } \\
\text { leadership and management }\end{array}$ & & {$[22] ;[33] ;[38]$} \\
\hline $\begin{array}{l}\text { Understand the organization } \\
\text { structure and organization } \\
\text { administration }\end{array}$ & & [19]; [34]; [38] \\
\hline $\begin{array}{l}\text { Understand organizational aim } \\
\text { and strategy }\end{array}$ & & [19]; [34]; [38] ; [39]; \\
\hline Area of competencies & $\begin{array}{l}\text { No. } \\
\text { of } \\
\text { Items }\end{array}$ & Sources \\
\hline $\begin{array}{l}\text { Practice professionalism in } \\
\text { management }\end{array}$ & & $\begin{array}{l}\text { [18]; [19]; [22]; [38]; } \\
\text { [39]; }\end{array}$ \\
\hline Ability to manage change & & {$[17] ;[20] ;[35] ;[38]$} \\
\hline $\begin{array}{l}\text { Develop facility management } \\
\text { strategy in line with } \\
\text { organizational strategy }\end{array}$ & & $\begin{array}{l}{[33] ;[34] ;[35] ;[39] ;} \\
{[16] ;[17] ;[19] ;[20]}\end{array}$ \\
\hline $\begin{array}{l}\text { Human resource management in } \\
\text { facility management work process }\end{array}$ & & $\begin{array}{l}{[17] ;[19] ;[20]:[22] ;} \\
{[34] ;[35] ;[36] ;[38] ;} \\
{[39]}\end{array}$ \\
\hline Effective communication & & $\begin{array}{l}{[18] ;[20] ;[22] ;[33] ;} \\
{[34] ;[35] ;[38]}\end{array}$ \\
\hline $\begin{array}{l}\text { Cooperation with suppliers and } \\
\text { specialists for matters/work } \\
\text { process related to facility } \\
\text { management }\end{array}$ & & [34]; [39] \\
\hline Logistics management & & [36] \\
\hline Workplace management rapport & & 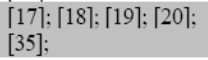 \\
\hline 2. Services Management & (9) & \\
\hline $\begin{array}{l}\text { Management matters on } \\
\text { organizational property }\end{array}$ & & $\begin{array}{l}{[16] ;[22] ;[33] ;[34] ;} \\
{[35] ;[36] ;[39]}\end{array}$ \\
\hline Understand building design & & {$[16] ;[22] ;[34] ;[38]$} \\
\hline $\begin{array}{l}\text { Maintenance of building elements } \\
\text { (roof, floor, external wall, stairs, } \\
\text { etc.) }\end{array}$ & & {$[34] ;[35] ;[39]$} \\
\hline Improve facility performance & & [35]; [38] \\
\hline Workplace management relation & & [22]; [39] \\
\hline $\begin{array}{l}\text { Manage building service systems } \\
\text { (e.g. Drainage, piping, sanitary, } \\
\text { safety, or electrical system, etc.) }\end{array}$ & & $\begin{array}{l}{[33] ;[34] ;[35] ;[39]} \\
{[17] ;[18] ;[22] ;[38]}\end{array}$ \\
\hline $\begin{array}{l}\text { Execute the contract management } \\
\text { works }\end{array}$ & & [36]; [38] \\
\hline $\begin{array}{l}\text { Manage support services (e.g. } \\
\text { Cleaning team, caterer/food } \\
\text { supplier, landscaping, etc.) }\end{array}$ & & [18]; [33]; [34]; [35] \\
\hline $\begin{array}{l}\text { Project management (includes } \\
\text { minor renovation } \\
\text { and repair/refurbishment etc.) }\end{array}$ & & $\begin{array}{l}{[16] ;[22] ;[33] ;[34] ;} \\
{[35] ;[36] ;[38] ;[39]}\end{array}$ \\
\hline $\begin{array}{l}\text { 2. Working Environment and } \\
\text { Resource Management }\end{array}$ & (8) & \\
\hline $\begin{array}{l}\text { Environmental issues (such as } \\
\text { recycling, energy saving, etc.) }\end{array}$ & & $\begin{array}{l}{[16] ;[18] ;[22] ;[33] ;} \\
{[34] ;[35] ;[36] ;[38]}\end{array}$ \\
\hline Space management & & $\begin{array}{l}{[18] ;[22] ;[34] ;[35] ;} \\
{[36] ;[38]}\end{array}$ \\
\hline $\begin{array}{l}\text { Consideration of the health, } \\
\text { safety and physical safety } \\
\text { management in the organization }\end{array}$ & & $\begin{array}{l}{[18] ;[22] ;[33] ;[36] ;} \\
{[38]}\end{array}$ \\
\hline $\begin{array}{l}\text { Works related to resource } \\
\text { procurement }\end{array}$ & & [34]; [35]; [38]; [39] \\
\hline $\begin{array}{l}\text { Risk management involved in the } \\
\text { work process done }\end{array}$ & & $\begin{array}{l}{[16] ;[17] ;[19] ;[34] ;} \\
{[35] ;[38]}\end{array}$ \\
\hline $\begin{array}{l}\text { Financial management in } \\
\text { managing organizational } \\
\text { resources }\end{array}$ & & $\begin{array}{l}{[17] ;[20] ;[22] ;[33] ;} \\
{[34] ;[35] ;[36] ;[38]} \\
{[39]}\end{array}$ \\
\hline $\begin{array}{l}\text { Quality management in managing } \\
\text { the organization resources }\end{array}$ & & $\begin{array}{l}\text { [16]; [17]; [19]; [33]; } \\
{[34] ;[38]}\end{array}$ \\
\hline $\begin{array}{l}\text { Information management in } \\
\text { managing the organization } \\
\text { resources }\end{array}$ & & [33]; [34]; [36];[39] \\
\hline $\begin{array}{l}\text { 4. Operations and Maintenance } \\
\text { Management }\end{array}$ & & (5) \\
\hline $\begin{array}{l}\text { Monitor the procurement, } \\
\text { installation, operation, } \\
\text { maintenance and disposition of } \\
\text { internal building system }\end{array}$ & & $\begin{array}{l}{[17] ;[18] ;[22] ;[33] ;} \\
{[34] ;[38]}\end{array}$ \\
\hline $\begin{array}{l}\text { Manage the building structure } \\
\text { and internal } \\
\text { permanent fittings maintenance }\end{array}$ & & $\begin{array}{l}{[17] ;[18] ;[22] ;[33] ;} \\
{[38]}\end{array}$ \\
\hline $\begin{array}{l}\text { Monitor the procurement, } \\
\text { installation, operation, } \\
\text { maintenance and disposal of } \\
\text { furniture and equipment. }\end{array}$ & & $\begin{array}{l}{[17] ;[18] ;[22] ;[33] ;} \\
{[38]}\end{array}$ \\
\hline $\begin{array}{l}\text { Monitor the procurement, } \\
\text { installation, operation, } \\
\text { maintenance and disposition of }\end{array}$ & & $\begin{array}{l}\text { [17]; [18]; [22]; [33]; } \\
{[34] ;[38]}\end{array}$ \\
\hline
\end{tabular}


TABLE I (b): CONTINUE

\begin{tabular}{|c|c|}
\hline $\begin{array}{l}\text { 4. Operations and Maintenance } \\
\text { Management }\end{array}$ & \\
\hline $\begin{array}{l}\text { Monitor the procurement, installation, } \\
\text { operation, } \\
\text { maintenance and disposition of } \\
\text { internal building system }\end{array}$ & $\begin{array}{l}{[17] ;[18] ;[22] ;[33] ;} \\
{[34] ;[38]}\end{array}$ \\
\hline $\begin{array}{l}\text { Manage the building structure and } \\
\text { internal } \\
\text { permanent fittings maintenance }\end{array}$ & $\begin{array}{l}{[17] ;[18] ;[22] ;[33] ;} \\
{[38]}\end{array}$ \\
\hline $\begin{array}{l}\text { Monitor the procurement, installation, } \\
\text { operation, } \\
\text { maintenance and disposal of furniture } \\
\text { and equipment. }\end{array}$ & $\begin{array}{l}{[17] ;[18] ;[22] ;[33] ;} \\
{[38]}\end{array}$ \\
\hline $\begin{array}{l}\text { Monitor the procurement, installation, } \\
\text { operation, } \\
\text { maintenance and disposition of } \\
\text { exterior building elements }\end{array}$ & $\begin{array}{l}{[17] ;[18] ;[22] ;[33] ;} \\
{[34] ;[38]}\end{array}$ \\
\hline $\begin{array}{l}\text { Implement operation and maintenance } \\
\text { management }\end{array}$ & $\begin{array}{l}{[17] ;[18] ;[22] ;[33] ;} \\
{[36] ;[38]}\end{array}$ \\
\hline 5. Law management & \\
\hline Acquire knowledge in real estate law & [36] \\
\hline Acquire knowledge of relevant related & $\begin{array}{l}{[16] ;[18] ;[20] ;[22] ;} \\
{[36] ;[38] ;[39]}\end{array}$ \\
\hline
\end{tabular}

\section{METHODOLOGY}

\section{A. Sample of the Study and Data Collection}

This study is a survey conducted in polytechnics of Malaysia. Based on the organizational chart on the website, the estimated population sample that manages facilities in the polytechnics is 1130 . Therefore the questionnaires also amounted in 1130 and 662 of questionnaires responses have been received. The method used by registered post to all polytechnics involved distributing of questionnaires to process and appoint an individual who is known at polytechnic institution for distribution and accumulation. While for polytechnic no connection, the questionnaire will be sent directly to the director of the polytechnic.

\section{B. The Questionnaire}

This study uses Facility Management Competencies Questionnaire (FMCQ) as a measuring tool. FMCQ are divided into four sections $\mathrm{A}, \mathrm{B}, \mathrm{C}$ and $\mathrm{D}$. For this article only the validity and reliability of section $\mathrm{A}$ will be discussed. A section FMCQ was used to measure five constructs in 36 items of facility management competencies. The constructs are Leadership in Organization and Human Resources Management, Services Management, Operation and Maintenance Management, Working Environment and Resource Management and Law Management. Likert scale used six options for individuals who manage the facility stated their degree of agreement on the items presented. It are terms of importance as a (6) Very important to (1) Direct Insignificant.

\section{Data Analysis}

The data of this study are based on respondents' scores (individual who manages the facility) of items in the questionnaire FMCQ. Scoring is based on Likert scale as described in the questionnaire survey section A. Data were reviewed manually before using Partial Least Square analysis technique (PLS). We tested the questionnaire based on structural equation modelling using Partial Least Squares (PLS) approach. We used the Smart PLS M2 Version 2.0 [40] software to analyse the data with the application of algorithm technique to determine the reliability and validity value.

\section{RESUlt AND DiscUSSION}

\section{A. Construct Validity}

Construct validity will confirm the extent to which the results obtained (e.g. questionnaires) are compatible and parallel to theoretical or conceptual [41]. A measurement tool is said to have construct validity if it succeeds measure theoretical structure has been developed. The question here is does the instrument tap the concept as theorised? This can be evaluated through convergent and discriminant validity.

\section{B. Convergent Validity}

Convergent validity is the degree to which multiple items used to measure the same concept are in agreement. This was assessed through composite reliability (CR), factor loadings and average variance extracted (AVE) [42]. The loadings for all items exceeded the recommended value of 0.5 [42]. Referring to Table II, all constructs have the value of CR more than 0.9 , which beyond the recommended value of 0.7 [42]. The average variance extracted (AVE) measures the variance captured by the indicators relative to measurement error, and it should be greater than 0.5 to justify using a construct [42]. The average variance extracted, were in the range of $0.557-0.860$.

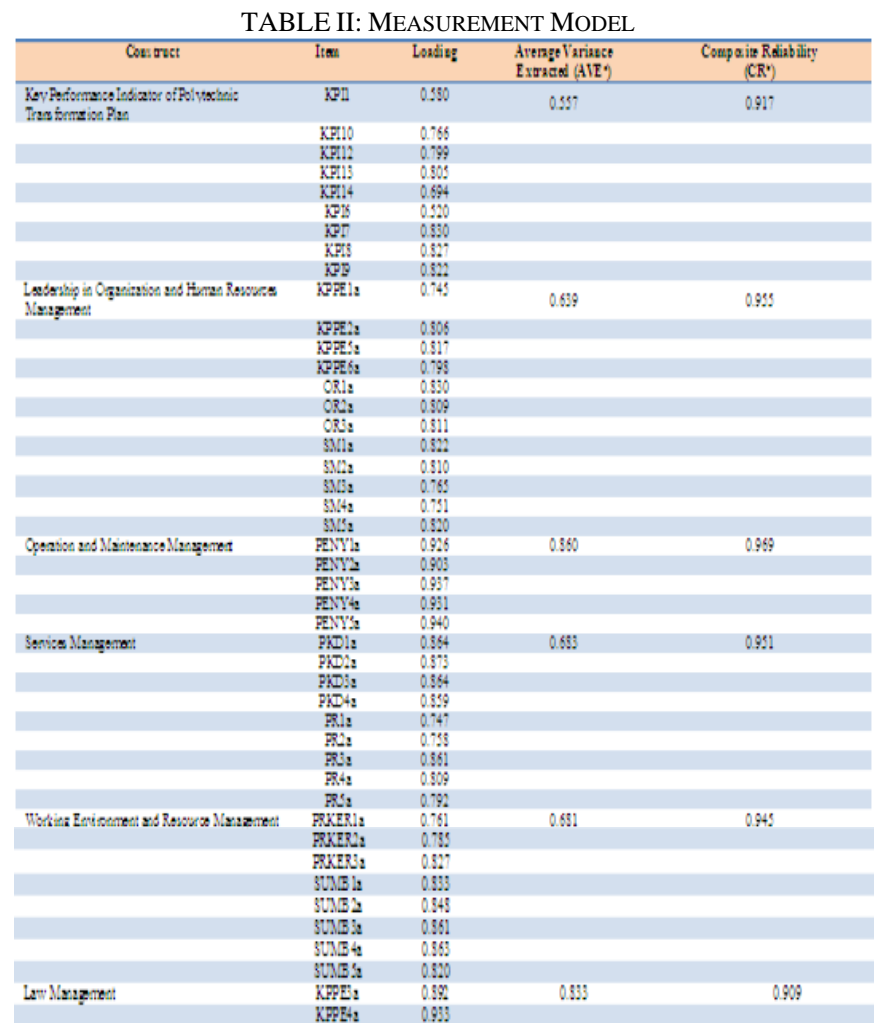

Note: ${ }^{a}$ Composite Reliability $(\mathrm{CR})=$ (square of the summation of the factor loadings) $/$ (square of the summation of the factor loadings) + (square of the summation of the error variances) $\}$

${ }^{\mathrm{b}}$ Average Variance Extracted $(\mathrm{AVE})=$ (summation of the square of the factor loadings $) /\{$ ( summation of the square of the factor loadings) + (summation of the error variances) $\}$

With the values obtained, it is shown that the use FMCQ convergent validity has allowed the literature and can be used for data collection.

\section{Discriminant Validity}

The discriminant validity of the measures (the degree to which items differentiate among constructs or measure 
distinct concepts) was assessed by examining the correlations between the measures of potentially overlapping constructs. Items should load more strongly on their own constructs in the model, and the average variance shared between each construct and its measures should be greater than the variance shared between the construct and other constructs [43]. As shown in Table III, the squared correlations for each construct are less than the average variance extracted by the indicators measuring that construct indicating adequate discriminant validity. In total, the measurement model demonstrated adequate convergent validity and discriminant validity.

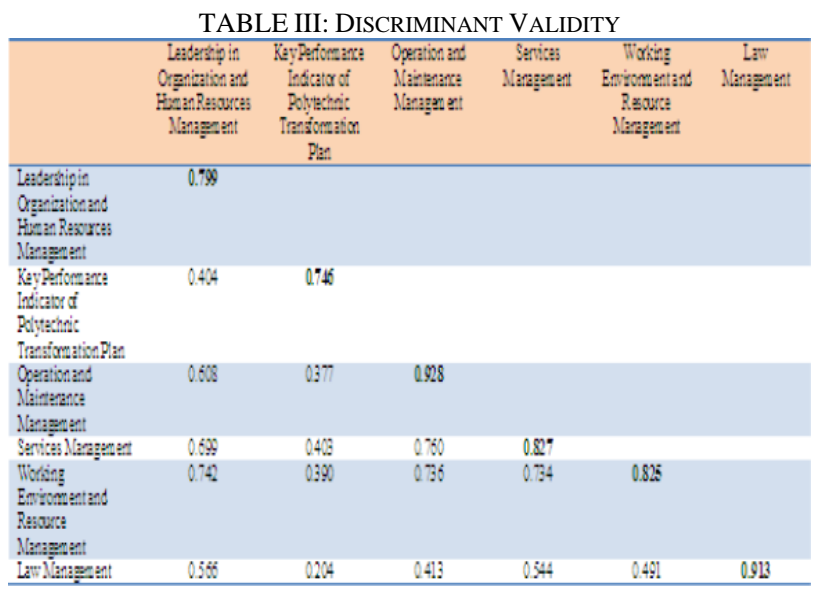

While Table IV shows the loadings and cross loading. The table shows that all items measuring the same construct loaded highly on that particular construct and loaded lower on other constructs indicating convergent and discriminant validity.

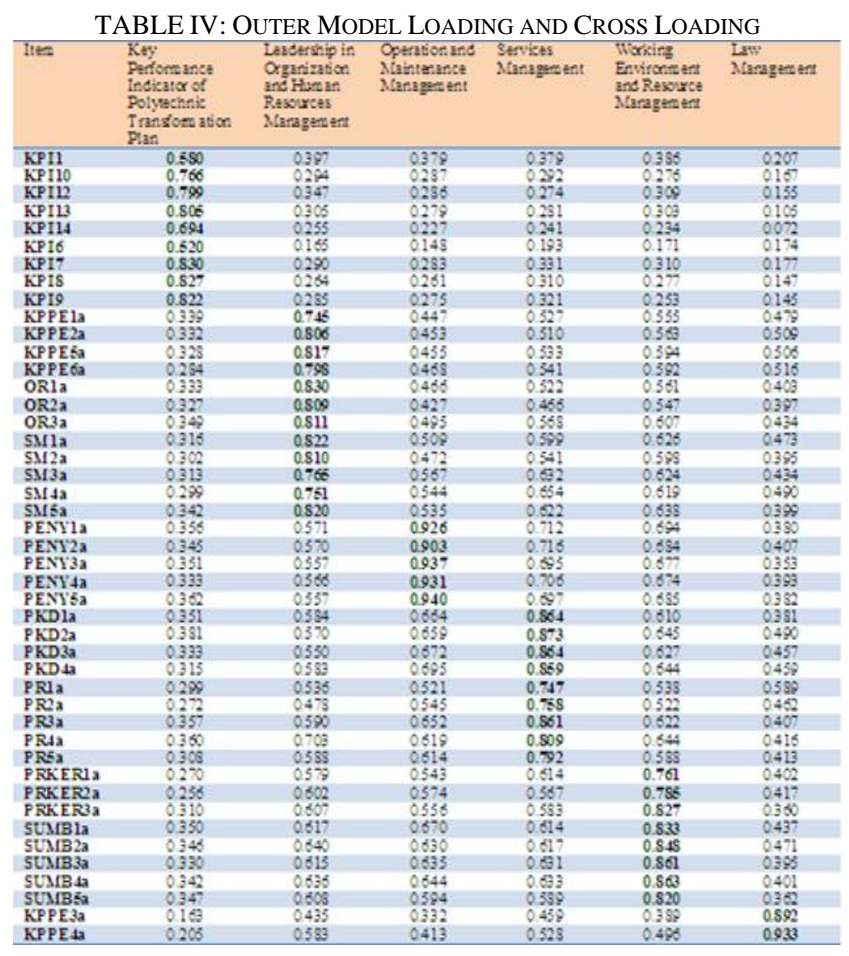

\section{CONCLUSION}

The result from the data analysis had to meet the criteria suggested by [16] for the reliability and validity FMCQ.
Accordingly, FMCQ particularly suitable for facility manager competencies information needed in polytechnics. Via these findings, the management of the polytechnic can make better planning for improvement in facilities management business. Generally, finding of the present study add to previous work on element of facility management competencies. The above findings hence contribute to our understanding of the basic competencies for facility manager. The limitation of the research derives, not involve all polytechnics in Malaysia._Thus the findings do not mean that it is suitable for all polytechnic, but the only polytechnic involved in that research. This research need to be continued in order to prove the element of competencies towards facility manager adoption. Therefore, it is suggested that further study is warranted in this area.

\section{ACKNOWLEDGMENT}

The research leading to these results has been partially supported from the Ministry of Higher Education Institution (MOHE), Malaysia under Federal Training Award 2010.

\section{REFERENCES}

[1] P. Roberts, "Corporate competence in FM: Current problems and issues," Facilities, vol. 19, no. 7/8, pp. 269-275, 2001.

[2] IFMA. (2013). Online International Facility Management Association [Online]. Available: http://www.fmlink.com/new/events

[3] BIFM. (2010). Online British Institute of Facilities Management. [Online]. Available: http:// www.bifm.org.uk/bifm/events

[4] FMAA. (2013). Online Facilities Management Association of Australia. [Online]. Available: http:// www.fmaonline.com.au/event

[5] M. Shaziman, Konvensyen pengurusan aset dan fasiliti kebangsaan (NAFAM), Kuala Lumpur, 2009.

[6] C. K. Prahalad and G. Hamel, Competing for the Future, Boston: Harvard Business School Press: ISBN 0-87584-716-1.1996.

[7] M. E. Porter, "The five competitive forces that shape strategy," Harvard Business Review, pp. 79-93, 2008.

[8] B. Melnikas, "Management specialists in the knowledge based society: Life-long learning oriented human resource development," Journal of Business Economics and Management, vol. 6, no. 3, pp. 155-170, 2005.

[9] F. P. Brooks, The Mythical Man Mouth, New York: Addison-Wesley, 1975.

[10] G. Zauda, Corporate Management in a Knowledge-Based Economy, New York: Palgrave Macmillan 2-80 ISBN 978-023029425, 2011.

[11] M. Hinton, Introducing Information Management, the Business Approach. Amsterdam, The Open University/Elsevier, pp. 205, ISBN 0-7506-6668-4, 2006.

[12] P. Doucek, R. Kuantova, and M. Maryska, "Do we have enough ICT specialist in the period of edependency? In creating solutions for the individual, organisations and society," University of Maibor, pp. 1-17, 2011.

[13] W. Wiersma, Research in Education: An Introduction, Boston: Allyn and Bacon, 2000.

[14] H. Braun and H. Wainer, "Value added modelling in Cir, Roa and S.Sinhary," (Eds.), Handbook of Statistics, Amsterderm: Elsevier, 2007, vol. 26

[15] J. R. Fraenkel and N. E. Wallen, How to design and Evaluate Research in Education, New York, NY: McGraw Hill, 2009.

[16] E. Clark and L. Hinxman, "Developing a framework of competencies for facilities management," Facilities, vol. 17, no. 7-8, pp. 246-252, 1999.

[17] D. Cameron and T. Markus, The Words Between The Spaces: Building and Language, London: Routledge, 2002.

[18] T. Payne, "Facilities management: A strategy for success," The Chandos Serries on Construction and Facilities, Chandos Publishing, Oxford, 2000.

[19] B. Atkins and A. Brooks, Total Facilities Management, Oxford, UK Blackwell Publishing, 2005.

[20] M. Van Den Ende, "Working in the field of facility management Theseus," in Proc. the Euro FM Conference, 2006.

[21] A. C. Hauptfleisch and J. J. P. Verster, "Facilities management: proposals for practice improvement and development support throught educational programmes in South Africa," Management and 
Innovation for a Sustainable Built Environment, ISBN: 978905269395820 - 23 June 2011, Amsterdam, The Netherlands. 2011.

[22] APPA. (2010). Leadership in Educational Facilities. [Online]. Available: http:// www.Appa.Org

[23] A. Mariah, M. Hakim, S. Maimunah, and A. R. Shahril, "Transformation of Malaysian polytechnic inevitabilities facility management competencies," Journal of Global Management; vol. 5, no. 1, pp. 1-20, 2013.

[24] J. L. R. Lopes, "Corporate real estate management features," Facilities, vol. 14, no. 7-8, 1996.

[25] I. Price and F. Akhlaghi, "New patterns in facilities management: Industry best practice new organizational theory," Facilities, vol. 22 , no. 13-14, 1999.

[26] PCA (Property Council of Australia), Unleashing Corporate Property Getting Ahead of the Pack, 2000.

[27] W. M. Gregor, "Preparing for an uncertain future," Facilities, vol. 18, 2000.

[28] J. Hinks, "All FM is non-core, but is some FM less core than others? A discussion on realizing the strategic potential of FM," FM Link White Paper, 2001.

[29] C. B. R. Langston and G. D. Valence, Workplace Strategies and Facilities Management: Building Value, Oxford: Butherworth-Heinemann, 2003.

[30] D. Cotts and E. P. Rondean, The Facility Managers Guide to Finance and Budgeting, New York, Amacon, 2004.

[31] P. A. Rodgers, "Performance matters: How the high performance business unit leverages facilities management effectiveness," Journal of Facilities Management, vol. 2, no. 4, 2004.

[32] C. M. J. Warren and S. K. Heng, "FM education-are we meeting industry needs," in Proc. PPRES 05: Pacific Rim Real Estate Society 11th Annual Conference, 2005, pp. 1-20.

[33] IFMA. (2010). International facility management association. [Online] Available: http://www.ifma.com

[34] BIFM. (2010). British Institute of Facilities Management. [Online]. Available: http://www.bifm.org.uk/bifm/home

[35] FMA Australia. (2010). Facilities Management Association on Australia. [Online]. Available: http://www.fma.com.au/cms/index.php

[36] HKIFM. (2010). Hong Kong Institute of Facilities Management. [Online]. Available: http://www.hkifm.org.hk

[37] CIDB Malaysia, Asset and Facility Management Implementation Manual, Construction Industry Development Board, Malaysia (CIDB), ISBN 9789675317415, 2011.

[38] National Research Council, "Core competencies for federal facilities asset management through 2020," Transformational Strategies, Washington D.C., The National Academic Press, 2008.

[39] RICS. (2010). Royal Institution of Chartered Surveyors. [Online]. Available: http://www. rics.org.

[40] C. M. Ringle, S. Wende, and A. Will, (2005). Smart PLS (Version 2.0.M3). Hamburg, Germany: University of Hamburg. [Online]. Available: http://www.smartpls.de.

[41] U. Sekaran and R. Bougie, Research Methods for Business: A Skill Building Approach, Wiley, London, 2010.
[42] J. F. Hair, W. C. Black, B. J. Babin, and R. E. Anderson, Multivariate Data Analysis, Upper Saddle River, NJ: Prentice-Hall, 2010.

[43] D. Compeau, C. A. Higgins, and S. Huff, "Social cognitive theory and individual reaction to computing technology: A longitudinal study," MIS Quarterly, vol. 23, no. 2, pp. 145-158. 1999.

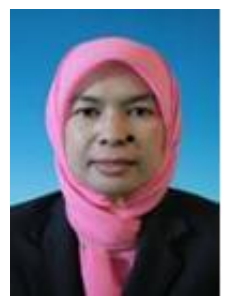

Mariah Awang was born on 6 July, 1971 at Tumpat, Kelantan, Malaysia. Her academic qualification is Diploma in Civil Engineering, Universiti Teknologi Malaysia, 1993; Bachelor of Civil Engineering (structure), Universiti Teknologi Malaysia, 1998; Master of Education, Universiti Teknologi Malaysia 1999; PhD Candidate, Facility Management, Universiti Teknologi Malaysia, 2010 - to date. The experience of the work she is as follows: Assistant Design Structure, Haikal Consultant, Johor, Malaysia, 1993-1994; Lecturer, Department of Mathematic Science and Computer, Polytechnic Johore Bahru, Johore, Malaysia, 1999-2010; Lecturer, Department of Civil Engineering, Polytechnic Sultan Idris Shah, Selangor, Malaysia, 2011-2012; Lecturer, Human Resources Division, Ministry of higher education Putrajaya, Malaysia, 2012- to date. She also Head of Mathematic unit, Department of Mathematic Science and Computer, Polytechnic Johore Bahru, Johore, Malaysia, 2000 - 2004; Assistant Head of Department, Department of Mathematic Science and Computer, Polytechnic Johore Bahru, Johore, Malaysia, 2005 - 2007; Head of Science unit, Department of Mathematic Science and Computer, Polytechnic Johore Bahru, Johore, Malaysia, 2008 - 2010.

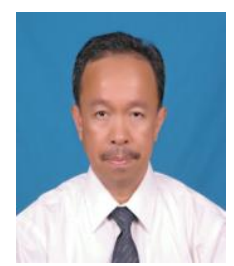

Abdul Hakim Mohammad was born on 5 July, 1959 at Kelang, Selangor, Malaysia. His academic qualification is Diploma in Quantity Surveying, Universiti Teknologi Malaysia, 1980; Bachelor of Quantity Surveying, Universiti Teknologi Malaysia, 1985; MSc Construction, Loughborough University of Technology, U.K., 1987; PhD Construction Management, University of London, U.K., 1994. The experience of the work he is as follows ; Assistant Quantity Surveyor, Public Work of Department, Malaysia, 1980-1983; Assistant Lecturer, Departmen of Property Management, Universiti Technologi Malaysia, 1985-1987; Lecturer, Department of Property Department, Universiti Technologi Malaysia, 1987-1996; Associate Professor, Department of Property Management, Universiti Teknologi Malaysia, 1996-2006 ; $\mathrm{He}$ also as Professor, Department of Real Estate, Faculty of Geoinformation and Real Estate, Universiti Teknologi Malaysia, 2006 -to-date. Deputy Dean 1, Research Management Centre, UTM, 1995-1999; Deputy Dean (Research and Post Graduate), Faculty of Geoinformation Science and Engineering, UTM, 2001 - 2005; Director, Centre for Real Estate Studies, Faculty of Geoinformation and Real Estate, UTM, (2007 - Jun 2013); Dean, Faculty of Geoinformation and Real Estate, UTM, (Julai 2013 - to date). 